\title{
Obstructive Sleep Apnoea and Type 2 Diabetes
}

\author{
Abd A Tahrani ${ }^{1}$ and Asad Ali ${ }^{2}$ \\ 1. NIHR Clinician Scientist, Centre of Endocrinology, Diabetes and Metabolism, University of Birmingham and Honorary Consultant Physician, \\ Department of Diabetes and Endocrinology, Heart of England NHS Foundation Trust, Birmingham, UK; 2. Consultant Respiratory Physician, \\ Department of Respiratory Medicine, University Hospital of Coventry and Warwickshire, Coventry, UK
}

\begin{abstract}
With the growing prevalence of obesity, the burden of type 2 diabetes is increasing. Obstructive sleep apnoea (OSA) is a very common medical condition that is associated with increased risk of cardiovascular disease and mortality. Obesity is a common risk factor for OSA and type 2 diabetes and hence it is not surprising that OSA and type 2 diabetes are interlinked. OSA has been shown to be an independent risk factor for the development of incident pre-diabetes/type 2 diabetes. OSA is also associated with worse glycaemic control and vascular disease in patients with type 2 diabetes. However, evidence for the benefits of OSA treatment in patients with type 2 diabetes is still lacking. The aim of this article is to provide an overview of OSA, the relationships between OSA and dysglycaemia and the impact of OSA in patients with type 2 diabetes, highlighting recent advances in the field.
\end{abstract}

\section{Keywords}

Diabetes, sleep apnoea, obesity, pre-diabetes, impaired glucose tolerance, hypertension, cardiovascular disease, retinopathy, nephropathy, neuropathy, glycated haemoglobin

Disclosure: Abd A Tahrani is a clinician scientist supported by the National Institute for Health Research. The views expressed in this article are those of the authors and not necessarily those of the NHS, the National Institute for Health Research or the Department of Health. The authors have no conflicts of interest to declare. Received: 3 February 2014 Accepted: 7 March 2014 Citation: European Endocrinology, 2014;10(1):43-50 DOI:10.17925/EE.2014.10.01.43 Correspondence: Abd A Tahrani, 2nd floor Institute of Biomedical Research, The Medical School, University of Birmingham, Birmingham B15 2T, UK. E: a.a.tahrani@bham.ac.uk

Diabetes is a global epidemic with an estimated worldwide prevalence of $8.3 \%$ (382 million) in 2013 that is forecast to rise to $10.1 \%$ (592 million) in 2035. ${ }^{1}$ Type 2 diabetes accounts for $>90 \%$ of all cases, and costs an estimated 10-12 \% of the world's health expenditure in 2010 to $2013 .^{1-3}$ In addition to the high prevalence of diabetes, 316 million people have impaired glucose tolerance (IGT) that is projected to increase to 471 million by $2035 .^{1}$

Type 2 diabetes is a complex metabolic disorder in which the interaction between multiple genetic and environmental factors results in a heterogeneous and progressive condition with variable degrees of insulin resistance (IR) and pancreatic $\beta$-cell dysfunction. ${ }^{4}$ Overweight and obesity are major contributors to the IR. ${ }^{4-6}$ When $\beta$-cells are unable to secrete sufficient insulin to overcome IR, type 2 diabetes ensues. ${ }^{4,6}$

Obstructive sleep apnoea (OSA) is a common disorder characterised by upper airway instability during sleep, resulting in markedly reduced (hypopnoea) or absent (apnoea) airflow.7 These apnoea/hypopnoea episodes are usually accompanied by recurrent oxygen desaturations and cyclical changes in blood pressure (BP) and heart rate and disturbances in sleep architecture such as loss of slow-wave sleep (SWS) and rapid eye movement (REM) sleep.

Although obesity is the main driver for $I R$ and $\beta$-cell dysfunction several aspects of sleep-related disorders have recently emerged as potentially important contributors to IR and to the development of IGT/type 2 diabetes. ${ }^{8}$ Short sleep duration and disturbances in the circadian rhythm are associated with IR and increase the risk of type 2 diabetes. ${ }^{9-12}$ Hence there is a lot of interest among endocrinologists and sleep specialists to further our understanding of the role of sleep in patients with dysglycaemia

The aim of this paper is to give an overview of OSA and review the evidence for the relationship between OSA and type 2 diabetes with particular focus on more recent studies.

\section{Obstructive Sleep Apnoea Definitions}

The American Academy of Sleep Medicine (AASM) guideline has defined an apnoea as cessation or $\geq 90 \%$ reduction in airflow for a period of $\geq 10$ seconds; hypopnoea has different definitions detailed in the AASM but a commonly used definition is $\geq 30 \%$ reduction in airflow for $\geq 10$ seconds associated with $\geq 4 \%$ drop in oxygen saturations. ${ }^{13}$ Apnoeas are classified into obstructive or central, based on the presence or absence of respiratory/abdominal efforts. Examples of apnoeas and hypopnoeas can be found in Figure 1. The apnoea-hypopnoea index (AHI) is the average number apnoea and hypopnoea episodes per hour during sleep and is a marker of OSA severity. ${ }^{7} \mathrm{An} \mathrm{AHI} \geq 5$ events/hour is consistent with the diagnosis of OSA:14 however, in the context of research, different studies in the literature used different AHI cut-offs to define OSA including 5, 10, 15 and 30 events/hour. OSA can be classified as mild, moderate and severe based on AHI 5 to $<15,15$ to $<30$ and $\geq 30$ events/hours. The respiratory disturbance index (RDI) is another OSA measure that includes the $\mathrm{AHI}$ in addition to respiratory effort-related arousal, which is defined as a sequence of breaths characterised by increasing respiratory effort leading to an arousal from sleep, but that 


\begin{abstract}
Figure 1: An Example of Apnoea (Red), Hypopnoeas (Pink) and Desaturations (Green) in a Patient with Obstructive Sleep Apnoea and Type 2 Diabetes
\end{abstract}

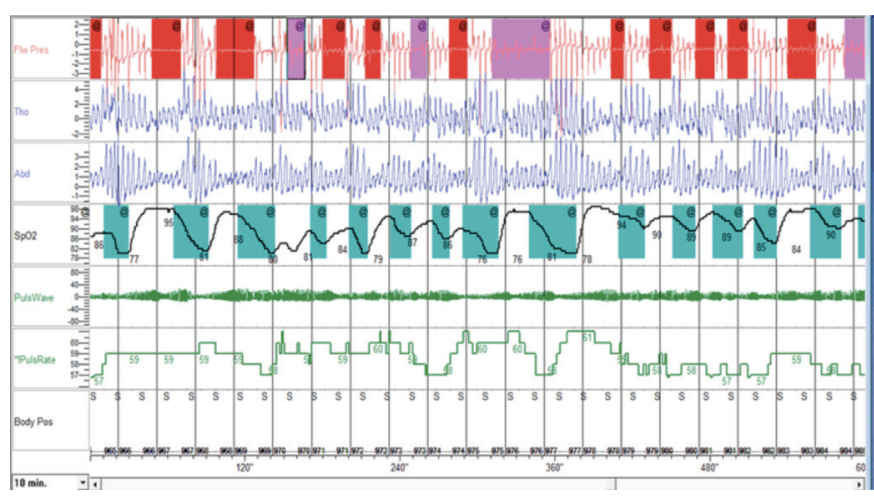

Note the the presence of thoracic and abdominal movements indicating the presence of obstructive rather than central sleep apnoea.

does not meet criteria for an apnoea or hypopnoea. ${ }^{7}$ Another measure of OSA is the oxygen desaturation index (ODI), which is the average number of oxygen desaturations per hour during sleep.

\section{Obstructive Sleep Apnoea Epidemiology and Risk Factors}

The prevalence of OSA varies considerably between studies, mainly due to differences in the population studied, study designs and the method and criteria used to diagnose OSA. In addition, as obesity and age are major risk factors for OSA, it is likely that OSA prevalence is increasing with the increasing prevalence of obesity and an ageing population. It is estimated that $17-26 \%$ of men and $9-28 \%$ of women have OSA and that 9-14\% of men and $2-7 \%$ of women have moderate to severe OSA..$^{15}$ This OSA prevalence is reported from studies that used a twostage sampling design that allows some degree of estimate of the 'selfselection' bias, which is usually a significant problem in OSA studies.

Ethnicity and gender have significant impacts on OSA prevalence. Some studies showed a higher adjusted OSA prevalence in Afro-Caribbeans (increased twofold) compared with White Europeans, ${ }^{15}$ while others did not confirm this. ${ }^{16}$ The Chinese population has a high OSA prevalence (8.8\% in men and $3.7 \%$ in women) despite being less obese than White Europeans, ${ }^{17,18}$ which highlights the importance of factors other than obesity (such as upper airway anatomy) in the development of OSA. ${ }^{19}$ In South Asians, OSA prevalence varies between $3.7 \%$ in a semi-urban population to $19.5 \%$ in middle-age urban men. ${ }^{20-22}$ Men have two to three times increased risk of OSA compared with women: ${ }^{15}$ differences in sex hormones, upper airway size and ventilatory control have been implicated in the gender differences. ${ }^{23,24}$ OSA prevalence in elderly men is three to six times that in younger men; $15,23,25$ however, this age effect plateaus around the age of 65 years. ${ }^{16}$ Changes in pharyngeal anatomy and upper airway collapsibility are likely responsible for the age impact on OSA prevalence. ${ }^{23}$

Excess body weight is by far the most important risk factor for OSA, although notall OSA patients are obese. In the Wisconsin sleep study, each increase in body mass index (BMI) by one standard deviation, resulted in a fourfold increase in OSA prevalence. ${ }^{26}$ Weight gain is a strong predictor of developing OSA or worsening of pre-existing OSA ${ }^{27,28}$ and weight loss (via lifestyle modifications or surgical intervention) improve/cure OSA. ${ }^{29,30}$ Several mechanisms might be responsible for the association between obesity and OSA. Obesity can alter normal upper airway mechanics during sleep by increased parapharyngeal fat deposition resulting in a smaller upper airway, altering the neural compensatory mechanisms that maintain airway patency, reducing the functional residual capacity with a resultant decrease in the stabilising caudal traction on the upper airway and affecting the chemosensitivity to $\mathrm{O}_{2}$ and $\mathrm{CO}_{2}$, which reduces ventilator drive. ${ }^{31}$ Other OSA risk factors include current smoking, excess alcohol intake and genetic factors. 15,23

\section{Obstructive Sleep Apnoea Pathophysiology}

OSA is a very complex disorder, and pathogenesis involves multiple mechanisms (see Figure 2). Upper airway size and collapsibility plays an important role; smaller airways are more likely to collapse. ${ }^{32}$ The presence of upper airway deficits in patients with OSA is supported by data showing that upper airway muscles (genioglossus) activity is increased in patients with OSA, ${ }^{33}$ suggesting that these muscles are compensating for an underlying upper airway deficiti ${ }^{32}$ and that continuous positive airway pressure (CPAP) treatment improves muscle hyperactivity. ${ }^{34}$ Sleep onset is associated with greater reductions in upper airway muscle tone in OSA patients, which explains the occurrence of apnoea/hypopnoea episodes at sleep onset and during REM sleep. ${ }^{32}$ Other factors contributing to OSA pathogenesis include changes in lung volume, abnormalities in ventilatory control and stability, changes in chemosensitivity to $\mathrm{CO}_{2}$ and higher arousal thresholds. ${ }^{32}$

\section{Obstructive Sleep Apnoea Clinical Features and Diagnosis}

A thorough history and examination are still essential parts of the assessment of patients with OSA despite the fact that several reports have shown the limited value of symptoms in predicting OSA. ${ }^{35}$ Snoring is the most common symptom of OSA and only $6 \%$ of OSA patients (or their partners) have not reported snoring. Snoring, however, has a poor predictive value as many snorers do not have OSA. ${ }^{7}$ Nonetheless, lack of snoring almost rules out OSA. ${ }^{7}$ Witnessed apnoeas are another important symptom that is usually reported by the partner. However, witnessed apnoeas do not correlate with disease severity and around $6 \%$ of the 'normal' population appear to have experienced apnoeas without OSA.' Other nocturnal symptoms such as choking (which is possibly a 'proper' rather than a 'micro' arousal to terminate apnoea), insomnia, nocturia and diaphoresis have been reported.? Daytime symptoms include EDS, fatigue, morning headache and autonomic symptoms.?

The gold standard to diagnose OSA is polysomnography that typically includes the recording of 12 channels such as electroencephalogram (EEG), electrooculogram (EOG), electromyogram (EMG), oronasal airflow, chest wall effort, abdominal effort, body position, snore microphone, electrocardiogram (ECG) and oxyhaemoglobin saturation.? Portable home-based respiratory devices are another alternative. ${ }^{7}$ Pulse oximetry is another good way to diagnose sleep apnoea but it cannot differentiate between obstructive and central apnoeas and it has a wide range of sensitivity (31-98\%) and specificity (41-100\%). The AASM recommends use of a type III device as a minimum.?

\section{Obstructive Sleep Apnoea as a Risk Factor for Type 2 Diabetes}

Several prospective studies have shown an increased risk of type 2 diabetes in patients with OSA and that OSA is an independent risk factor for incident type 2 diabetes after adjustment for age, obesity and other possible confounders. ${ }^{36-42}$ Most of these studies used polysomnography to diagnose OSA, but these included a relatively small number of 
participants as polysomnography is time-consuming and requires significant resources. The diagnosis of type 2 diabetes in these studies was mostly based on 'physician diagnosis' or fasting plasma glucose. However, more recent studies that used oral glucose tolerance tests to assess glycaemic status found similar results to other studies (see Table 1). A meta-analysis of published studies that used objective measures to diagnose OSA found that moderate to severe (but not mild) OSA was associated with increased risk of developing type 2 diabetes (moderate to severe OSA: relative risk [RR] 1.63, $95 \%$ confidence interval [CI] 1.092.45; mild OSA RR 1.22, $95 \% \mathrm{Cl} 0.91-1.63) .{ }^{43}$

The impact of OSA on incident type 2 diabetes is likely to be related to its impact on IR and $\beta$-cell dysfunction. While some cross-sectional studies showed an association between OSA and IR, ${ }^{44-64}$ others did not. ${ }^{65-71}$ Several factors might be responsible for these conflicting results Studies that did not show such an association typically included fewer participants and were possibly underpowered. Variation in excessive daytime sleepiness (EDS), which has been shown to be associated with $\mathbb{I R}_{1}^{72,73}$ between study populations might also contribute to the variation in results. Further evidence for the relationship between OSA and IR comes from a study which assessed the impact of OSA on IR (homeostatic model assessment [HOMA]-IR) longitudinally over 11year follow-up. This showed that OSA, AHI, ODI and minimal oxygen saturations were independently associated with IR after adjustment for age, baseline BMI, hypertension, BMI change over follow-up and CPAP treatment. ${ }^{42}$ CPAP treatment was shown to lower IR in some studies ${ }^{74,75}$ but not in others. ${ }^{48,65,76-78}$ However, several meta-analyses showed that CPAP treatment lowers $\mathbb{I R}^{79,80}$ particularly in those compliant with treatment and using CPAP $>4$ hours per night. ${ }^{81}$

Obesity remains a major possible confounder for the relationship between OSA and IR. Recent studies tried to address this matter by reassessing this association in lean individuals. ${ }^{82,83}$ Healthy lean men (BMI $22.6 \mathrm{~kg} / \mathrm{m}^{2}$ ) with OSA had $27 \%$ lower insulin sensitivity and $37 \%$ higher insulin secretion than age, BMI, family history and exercise levelmatched control after ingestion of a glucose load despite comparable glucose levels between groups. ${ }^{82}$ This suggests that OSA in lean men is associated with $\mathbb{R}$ and a compensatory rise in insulin secretion to maintain normoglycaemia. Another study showed that OSA was associated with dysglycaemia/pre-diabetes in lean but not obese Koreans. ${ }^{84}$ Furthermore, in conditions in which IR is not driven by obesity, such as acromegaly, OSA has been associated with IR and dysglycaemia. ${ }^{85}$ Hence it is likely that OSA is associated with IR independent of obesity and that this is amenable to treatment with CPAP.

Contrary to the relationship between OSA and IR, the impact of OSA on $\beta$-cells is rather limited. In vitro and animal studies showed that intermittent hypoxia increases $\beta$-cell death, and results in $\beta$-cell dysfunction, ${ }^{86,87}$ but the intermittent hypoxia used in these studies was greater than that which occurs in humans with OSA. Two studies in humans showed that OSA was associated with $\beta$-cell dysfunction in patients with ${ }^{88}$ and without type 2 diabetes. ${ }^{44}$ Much more data are needed in terms of the longitudinal impact of OSA on $\beta$-cells and the impact of CPAP.

\section{Type 2 Diabetes as a Risk Factor for Obstructive Sleep Apnoea}

Unlike the well-examined impact of OSA on the risk of developing type 2 diabetes, the impact of type 2 diabetes on OSA incidence and the natural history of OSA have not been examined. It is plausible

\section{Figure 2: Summary of the Pathogenesis of Obstructive Sleep Apnoea}

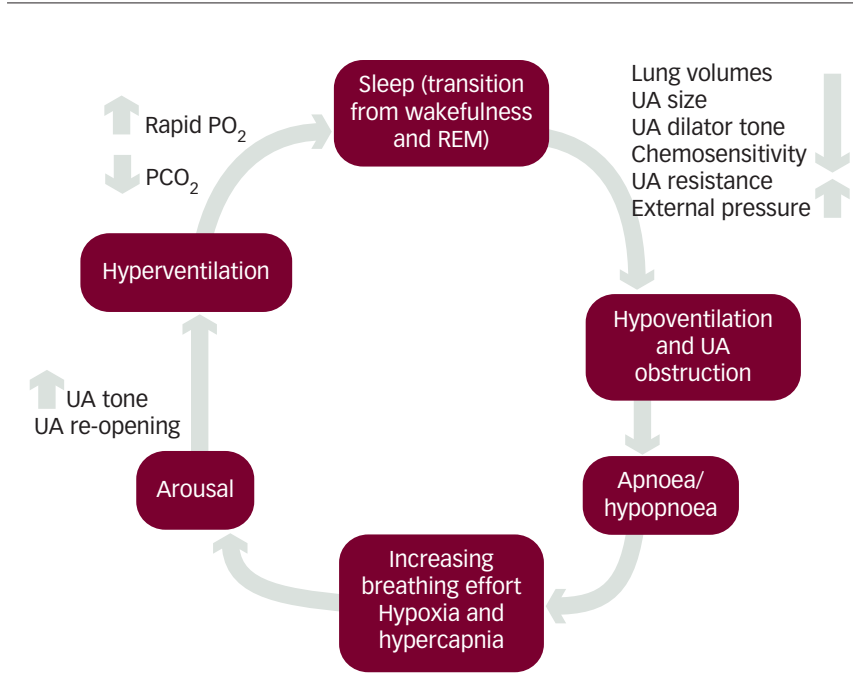

REM = rapid eye movement; $U A$ = upper airway.

that type 2 diabetes could result in the development or worsening of pre-existing OSA. This might be related in part to the weight gain that occur in patients with type 2 diabetes with treatment intensification (particularly in the pre-incretin therapy era) and weight gain is a strong predictor of developing OSA or worsening of pre-existing OSA. ${ }^{27,28}$ Other possible mechanisms include loss of upper airway innervations or the autonomic dysfunction that can occur in patients with type 2 diabetes, which is implicated in the central respiratory centre response to hypercapnic stimulus ${ }^{89}$ and may result in changes in respiratory control resulting in sleep apnoea. ${ }^{90}$

One study has examined the presence of witnessed sleep apnoeas (sleep reported) in 3,565 participants at baseline and after 6 years and found that HOMA-IR was an independent predictor of incident witnessed apnoeas (odds ratio [OR] 1.31 [1.13-1.51]) after adjustment for age, sex and waist circumference. ${ }^{11}$ Other independent predictors of witnessed sleep apnoeas included waist circumference (1.34 [95\% Cl 1.19-1.52]), triglycerides (1.24 [1.09-1.41]) and smoking (1.52 [1.12$2.05]^{91}$ - all of these factors might confer an increased risk of OSA in patients with type 2 diabetes.

Future studies need to examine the natural history of sleep apnoea (both obstructive and central) in patients with type 2 diabetes as this information will be important to develop the appropriate screening strategies for sleep apnoea in patients with type 2 diabetes and to understand the metabolic and non-metabolic consequences of sleep apnoea in patients with type 2 diabetes. The ongoing Sleep AHEAD study might provide some useful information about the natural history of OSA in patients with type 2 diabetes.

\section{Obstructive Sleep Apnoea Prevalence in Patients with Type 2 Diabetes}

Obesity is a major risk factor for OSA and type 2 diabetes and, as described above, OSA is an independent predictor of incident type 2 diabetes and is associated with IR and $\beta$-cell dysfunction. Hence, it is not surprising that several epidemiological studies showed that OSA is very common in patients with type 2 diabetes (8.5-85\%,23.8-70\% for moderate to severe OSA). ${ }^{64,92-103}$ Methodological and population differences account for the significant differences observed between studies in OSA prevalence. 


\section{Table 1: Prospective Studies that Examined the Association between Obstructive Sleep Apnoea and Incident Type 2 Diabetes}

\begin{tabular}{|c|c|c|c|c|}
\hline $\begin{array}{l}\text { Author(s)/ } \\
\text { Study/Country }\end{array}$ & Population & $\begin{array}{l}\text { Follow-up } \\
\text { (Years) }\end{array}$ & $\begin{array}{l}\text { Type } 2 \text { Diabetes } \\
\text { Diagnosis }\end{array}$ & Results \\
\hline $\begin{array}{l}\text { Elmasry et al. }{ }^{* 36} \\
\text { 2000/Sweden }\end{array}$ & $\begin{array}{l}2,668 \text { (all men, } \\
\text { aged } 30-69 \\
\text { years) }\end{array}$ & 10 & Questionnaire & $\begin{array}{l}\text { Diabetes development: } 5.4 \% \text { versus } 2.4 \% \text { with versus } \\
\text { without habitual snoring respectively }(p<0.001) .13 .5 \% \\
\text { versus } 8.6 \% \text { for obese snorers versus obese non-snorers } \\
\text { respectively }(p=0.17) \text {. OR ( } 95 \% \mathrm{Cl}) 7.0(2.9-16.9) \text { versus } \\
5.1(2.7-9.5) \text { for obese snorers versus obese non-snorers }\end{array}$ \\
\hline $\begin{array}{l}\text { Al-Delaimy } \\
\text { et al. }{ }^{* 37} 2002 / \text { S }\end{array}$ & $\begin{array}{l}69,852 \text { (all } \\
\text { female nurses) }\end{array}$ & 10 & $\begin{array}{l}\text { Self reported and } \\
\text { questionnaire }\end{array}$ & $\begin{array}{l}\text { Snoring was associated with risk of diabetes (occasional } \\
\text { versus non-snoring, RR 1.48, } 95 \% \mathrm{Cl} \text { 1.29-1.70; regular } \\
\text { versus non-snoring, RR 2.25, } 95 \% \mathrm{Cl} 1.91-2.66 \text { ) }\end{array}$ \\
\hline $\begin{array}{l}\text { Reichmuth et al. } \$ 38 \\
\text { 2005/US }\end{array}$ & 1,387 & 4 & $\begin{array}{l}\text { FPG physician } \\
\text { diagnosis }\end{array}$ & $\begin{array}{l}\text { Adjusted OR for developing diabetes with an AHI of } 15 \\
\text { or more: } 1.62 \text { ( } 95 \% \text { Cl 0.67-3.65) }\end{array}$ \\
\hline $\begin{array}{l}\text { Marshall et al. }{ }^{\$ 39} \\
\text { 2009/Australia }\end{array}$ & 295 & 4 & $\begin{array}{l}\text { Physician diagnosis } \\
\text { or FPG }\end{array}$ & $\begin{array}{l}\text { Moderate-severe OSA was an independent risk factor } \\
\text { for incident diabetes (OR=13.45, } 95 \% \mathrm{Cl} 1.59-114.11)\end{array}$ \\
\hline
\end{tabular}

\begin{tabular}{|c|c|c|c|c|}
\hline $\begin{array}{l}\text { Botros et al. }{ }^{40} \\
\text { 2009/US }\end{array}$ & 544 & 2.7 & $\begin{array}{l}\text { Physician diagnosis } \\
\text { and FPG }\end{array}$ & $\begin{array}{l}\text { Adjusted HR per quartile of OSA severity }=1.43 \\
(95 \% \mathrm{Cl} 1.10-1.86)\end{array}$ \\
\hline $\begin{array}{l}\text { Celen et al. }{ }^{\$ 41} \\
\text { 2010/Sweden }\end{array}$ & $\begin{array}{l}168 \text { (from a } \\
\text { sleep clinic) }\end{array}$ & 16 & Physician diagnosis & $\begin{array}{l}\text { Incident type } 2 \text { diabetes: } 15.5 \% \text { versus } 24.6 \% \text { ( } p=0.02 \text { ). } \\
\text { OSA was a predictor of incident type } 2 \text { diabetes in } \\
\text { women (OR 11.8, } 95 \% \mathrm{Cl} 1.1-121.7, \mathrm{p}=0.04 \text { ) but not } \\
\text { men after adjustment }\end{array}$ \\
\hline $\begin{array}{l}\text { Lindberg et al. }{ }^{* 42} \\
\text { 2012/Sweden }\end{array}$ & 141 (all men) & 11 & OGTT & $\begin{array}{l}\text { ODI }>5 \text { was a predictor of developing diabetes } \\
\text { (adjusted OR } 4.4,95 \% \mathrm{Cl} 1.1-18.1 \text { ) }\end{array}$ \\
\hline
\end{tabular}

Notes

Adjusted for: age, weight gain, smoking, alcohol dependence and physical inactivity

Adjusted for: age and BMI

Adjusted for: age, sex and body habitus

Adjusted for: age, gender, waist circumference, BMI, BP and HDL. Large $95 \% \mathrm{Cl}$ due to small number of incident diabetes OSA defined as $A H I \geq 8$. Adjusted for: age, sex, race, BMI, baseline fasting glucose and weight change Adjusted for: age and BMI

Patients in these studies were free from type 2 diabetes at baseline Obstructive sleep apnoea (OSA) diagnosis based on *questionnaire **overnight respiratory monitoring spolysomnography. $\mathrm{AHI}=$ apnoea-hypopnoea index; $\mathrm{BMI}=$ body mass index; $\mathrm{BP}=$ blood pressure; $\mathrm{Cl}=$ confidence interval; $C P A P=$ continuous positive airway pressure; $F P G=$ fasting plasma glucose; $H D L=$ high-density lipoprotein cholesterol; $H R=$ hazard ratio; ODI = oxygen desaturation index; OGTI = oral glucose tolerance test; OR = odds ratio; RR = risk ratio.

Studies with lower OSA prevalence tended to include a White European population and were conducted in primary care settings, $94,02,103$ while studies of higher prevalence were conducted in secondary care settings or included Afro-Caribbeans. ${ }^{97,01}$ Data regarding the prevalence of OSA in South Asians with type 2 diabetes is limited to one study that showed a higher prevalence in White Europeans compared with South Asians with type 2 diabetes, but the South Asians in this study had lower BMI and waist circumference that White Europeans. ${ }^{101}$ As OSA is common in patients with type 2 diabetes, the international Diabetes Federation (IDF) recommended screening for OSA in this high-risk population, ${ }^{104}$ although the extent to which this recommendation is followed is to be determined and appropriate validated screening methods in patients with type 2 diabetes are still lacking. Whether the prevalence of OSA is higher in patients with type 2 diabetes compared with similar populations without type 2 diabetes remains unclear.

\section{Obstructive Sleep Apnoea and Glycaemic Control in Patients with Type 2 Diabetes}

Due to its association with obesity, IR and $\beta$-cell dysfunction, it is plausible to speculate that OSA might worsen glycaemic measures in patients with type 2 diabetes. However, as with most aspects of OSA-related research, obesity is a major confounder. Several studies of relatively small sample size $(n=31-92)$ showed that OSA and OSA severity are associated with poorer glycaemic control (both glycated haemoglobin $\left[\mathrm{HbA}_{1 \mathrm{c}}\right]$ and fasting plasma glucose) and glycaemic variability after adjustments for age, sex, race, BMI, number of diabetes medications, level of exercise, years of diabetes and total sleep time in some studies. ${ }^{100,105-108}$ The adjusted mean increase in $\mathrm{HbA}_{1 \mathrm{c}}$ between patients with and without OSA varied between 0.7 to $3.69 \%$ depending on the OSA severity. However, not all studies showed such an association;, 95 however, in this study only $22 \%$ of participants had full polysomnography and the duration of the sleep study was just 4 hours. ${ }^{109}$ Another study showed no association between AHI and $\mathrm{HbA}_{1 \mathrm{C}}$ in patients with type 2 diabetes after adjustment for confounders but there was an association between lowest oxygen saturation

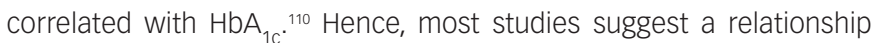
between OSA and glycaemic measures in patients with type 2 diabetes, but some studies did not show such an association and causation is difficult to prove due to the cross-sectional nature of these studies, the confounding effects of obesity and the lack of prospective studies assessing the impact of OSA on $\mathrm{HbA}_{1 \mathrm{c}}$ longitudinally.

To further add to the complexity, recent data suggest that the association between $\mathrm{HbA}_{1 \mathrm{c}}$ and OSA in patients with type 2 diabetes is dependent on the sleep stage by showing that AHI is independently associated with $\mathrm{HbA}_{1 \mathrm{C}}$ during REM but not during non-REM sleep. ${ }^{111}$ The difference in $\mathrm{HbA}_{1 \mathrm{C}}$ between the lowest and highest REM AHI quartile was about $1 \%{ }^{111}$ This could explain some of the variability observed in previous studies as patients with similar total AHI might have different distributions of REM and non-REM AHI.

Several studies examined the impact of CPAP treatment on glycaemic measures in patients with type 2 diabetes, ${ }^{76,92,112-117}$ only one of which was randomised ${ }^{76}$ with the rest being uncontrolled pre-post assessments. The uncontrolled studies showed improvements in insulin sensitivity, ${ }^{92,112}$ postprandial hyperglycaemia, ${ }^{113}$ glycaemic variability ${ }^{116}$ and/or $\mathrm{HbA}_{1 c^{\circ}}{ }^{113,114}$ The one randomised controlled trial showed no change in $\mathrm{HDA}_{1 \mathrm{C}}$ after 3 months of CPAP therapy. The lack of a positive effect could be attributed to the small study sample, the limited duration of follow-up and the suboptimal adherence to CPAP (3.6 hours/night), or to a true lack of 
effect. A meta-analysis found that CPAP did not significantly reduce $\mathrm{HbA}_{1 \mathrm{c}}(0.08 \%$ [95 \% $\mathrm{Cl}-0.26$ to 0.42$)$ in patients with type 2 diabetes. ${ }^{80}$

The association between REM AHI with $\mathrm{HbA}_{1 \mathrm{c}^{\prime}}$ rather than non REM AHI (described above), is another factor to be taken into account. Most of the REM sleep occurs towards the end of the night, hence longer usage of CPAP might be needed to produce an effect on glycaemic measures. This was tested in a recent study presented in the SLEEP 2013 conference where patients with type 2 diabetes (mean BMl $39.2 \mathrm{~kg} / \mathrm{m}^{2}$, diabetes duration 3.2 years), were randomised to 1 week in-laboratory (8 hours sleep) CPAP or sham CPAP to maximise CPAP adherence under direct supervision. CPAP resulted in a decrease of 11.2 and $19.8 \mathrm{mg} / \mathrm{dl}$ in the average 24-hour and post-breakfast glucose levels, respectively. The dawn phenomena was also reduced by $45 \% .{ }^{118}$ In addition to the better CPAP usage reported in this study, the diabetes duration was also relatively short, which might contribute to the CPAP effect.

Further randomised controlled trials are needed to assess the impact of CPAP on glycaemic control in patients with type 2 diabetes; these trials might need to focus on better CPAP compliance, longer CPAP usage per night and possibly targeting patients with shorter diabetes duration. Another completed randomised trial (Effect of PAP Treatment on Glycemic Control in Patients With Type 2 Diabetes [GLYCOSA]) should report soon (http://clinicaltrials.gov/ct2/show/study /NCT00509223?sect=X6015).

\section{Obstructive Sleep Apnoea and Hypertension in Patients with Type 2 Diabetes}

The links between OSA and arterial hypertension and the impact of CPAP treatment on BP in patients without diabetes are well established. ${ }^{119-124}$ Emerging evidence suggests that the same might be true in patients with type 2 diabetes. In a retrospective cohort study in patients with OSA and type 2 diabetes, CPAP was associated with a mean change of $-6.81 \mathrm{mmHg}(95 \% \mathrm{Cl}-9.94$ to $-3.67 \mathrm{mmHg}$ ) and $-3.69 \mathrm{mmHg}(-5.53$ to $-1.85 \mathrm{mmHg}$ ) in systolic and diastolic BP, respectively, after nine to 12 months of treatment. ${ }^{225} \mathrm{~A}$ randomised parallel group intervention trial showed similar results after 3 months of CPAP treatment. ${ }^{126}$ Randomised placebo and active controlled studies are needed.

\section{Obstructive Sleep Apnoea and Vascular Complications in Patients with Type 2 Diabetes}

Macro and micro-vascular complications remain the major cause of morbidity and mortality in patients with type 2 diabetes. Several lines of evidence suggest increased risk of cardiovascular disease (CVD) in patients with OSA and observational studies suggest that CPAP treatment is associated with reduction in CVD. ${ }^{127-129}$ In addition, in patients with stable coronary artery disease, $\mathrm{AHI}$ correlated positively with the plaque volume assessed by intravascular ultrasound $(r=0.6$; $\mathrm{p}=0.01)^{130}$ or computed tomography $(\mathrm{CT})$ angiogram $(r=0.4 ; \mathrm{p}=0.02){ }^{131}$ Furthermore, patients with OSA are more likely to develop acute myocardial infarction between 12 am and 6 am compared with nonOSA patients matched for comorbidities ( $32 \%$ versus $7 \%$; $p=0.01$ ) supporting the role of the nocturnal events that occur in OSA patients in the development of CVD. ${ }^{132}$

Data regarding the impact of OSA on CVD in patients with type 2 diabetes are limited. A cross-sectional analysis from the Look AHEAD study showed that $\mathrm{AHI}$ is associated with stroke (adjusted OR 2.57, $95 \% \mathrm{Cl}$ 1.03-6.42), but there was no association with coronary artery disease, ${ }^{133}$ but the CVD was self-reported. In a more recent study of 132 consecutive asymptomatic patients with type 2 diabetes and normal exercise echocardiographic findings for $\leq 8$ years, sleep disordered breathing (SDB) was associated with incident coronary artery disease (adjusted hazard ratio $[\mathrm{HR}] 2.2,95 \% \mathrm{Cl}$ 1.2-3.9; $\mathrm{p}=0.01$ ) and heart failure (adjusted HR $3.5,95 \%$ Cl 1.4-9.0; $p<0.01$ ) after a median follow-up of 4.9 years. ${ }^{134}$

Several studies examined the relationship between OSA and diabetesrelated microvascular complications - most of these studies were crosssectional in nature and interventional data are lacking. In Japanese patients undergoing vitreous surgery for advanced diabetic retinopathy (DR), lower oxygen saturations were associated with proliferative DR after adjustment for age, $\mathrm{HbA}_{1 \mathrm{C}}$ and hypertension. ${ }^{135}$ In a study from the UK, OSA was independently associated with DR and maculopathy after adjusting for age, $\mathrm{BMI}$, diabetes duration and hypertension in men with type 2 diabetes. ${ }^{136}$ Similarly, in another study from the UK, patients with OSA were three to four times more likely to have sight-threatening DR, preproliferative/proliferative DR or maculopathy after adjustment for a wide range of confounders including gender and ethnicity. ${ }^{137}$ Longitudinally, patients with OSA were more likely to develop advanced DR (adjusted OR 6.6, 95 \% Cl 1.2-35.1; $\mathrm{p}=0.03$ ); and patients who were compliant with CPAP treatment had lower progression to advanced DR compared with non-complaint patients. ${ }^{137}$ In a proof of concept uncontrolled, hypothesis-generating study, CPAP treatment for 6 months was associated with improvement in visual acuity without an impact on macular oedema/thickness. ${ }^{138}$

Similar to the associations with DR, OSA was found to be associated with diabetic nephropathy (defined as albuminuria and/or reduced eGFR) in patients with type 2 diabetes after adjustment for possible confounder. ${ }^{139}$ After a 2.5-year follow-up of the same cohort, OSA was an independent predictor of study-end eGFR and eGFR decline. ${ }^{139}$ In a study of Japanese patients with type 2 diabetes, ODI $\geq 5$ was independently associated with microalbuminuria in women but not in men after adjustment for confounders. ${ }^{140}$

A cross-sectional study found that patients with OSA were more likely to have diabetic neuropathy (OR 2.82, $95 \% \mathrm{Cl} 1.44-5.52)$ and foot insensitivity (OR 3.97; 95 \% Cl 1.80-8.74 ) compared with those without OSA. ${ }^{101}$

Several mechanisms might explain the observed associations between OSA and vascular disease in patients with type 2 diabetes. Hyperglycaemia and OSA result in the activation of similar pathways (e.g. Aldose reductase, protein kinase $\mathrm{C}$, advanced glycation end products) and increased oxidative and nitrosative stress that can lead to increased inflammation, cellular and endothelial dysfunction and vascular disease (see Figure 3). ${ }^{141-162}$ In recent studies, OSA was associated with increased oxidative stress, nitrosative stress and impaired microvascular complications in patients with type 2 diabetes. ${ }^{101,139}$

\section{Obstructive Sleep Apnoea and Type 2 Diabetes - The Mechanisms}

The mechanisms underlying the relationship between OSA and type 2 diabetes are likely to be complex and multifactorial involving multiple neural and endocrine pathways (see Figure 4).

Intermittent hypoxia is an important component of OSA and contributes significantly to its pathological consequences. Intermittent hypoxia for as little as 5 hours in healthy volunteers can reduce insulin sensitivity without a compensatory increase in insulin secretion, suggesting an impact on $\beta$-cell function as well. ${ }^{163}$ The intermittent hypoxia and the repetitive episodes of re-oxygenation following desaturations that 


\section{Figure 3: Proposed Mechanisms Relating Obstructive Sleep Apnoea to Microvascular Complications in Patients with Type 2 Diabetes}

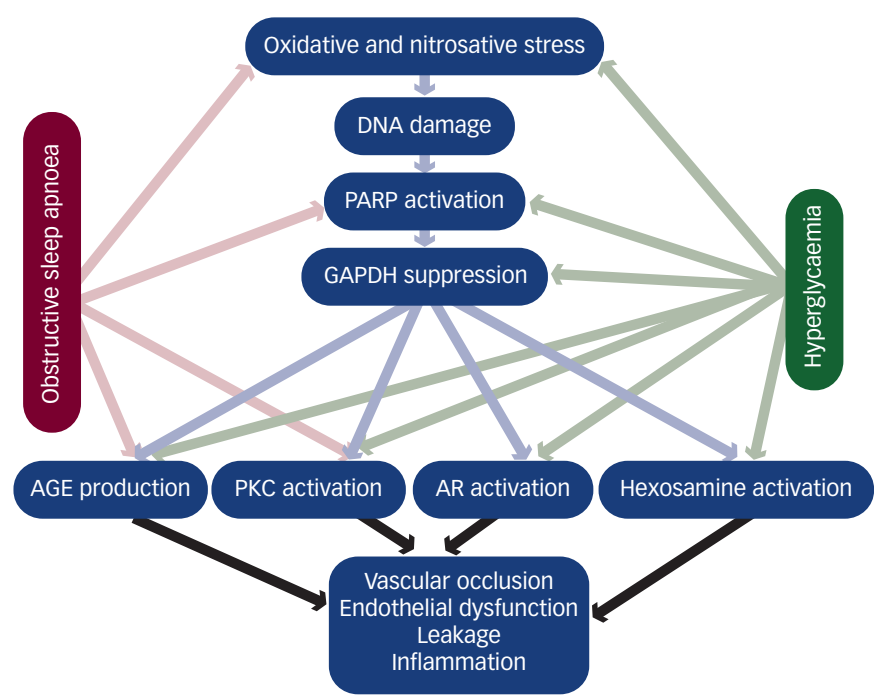

The figure shows the possible mechanisms in which hyperglycaemia can result in microvascular complications and the potential mechanisms in which obstructive sleep apnoea (OSA) can contribute to the development of microvascular complications in diabetes. Both OSA and hyperglycaemia share similar molecular mechanisms including oxidative stress, protein kinase C (PKC) activation and advanced glycation end product (AGE) production. Our own work has shown that patients with OSA and type 2 diabetes have increased oxidative and nitrosative stress and impaired microvascular complications compared with patients with type 2 diabetes only 107 and that patients with OSA and type 2 diabetes have poly ADP ribose polymerase (PARP) activation compared with patients without type 2 diabetes (unpublished data). $A R=$ aldose reductase; GAPDH = glyceraldehyde 3-phosphate dehydrogenase.

\section{Figure 4: Possible Mechanistic Linking Obstructive Sleep Apnoea to Dysglycaemia}

\section{OSA}

Sleep fragmentation-chronic intermittent hypoxia-loss or REM and SWS

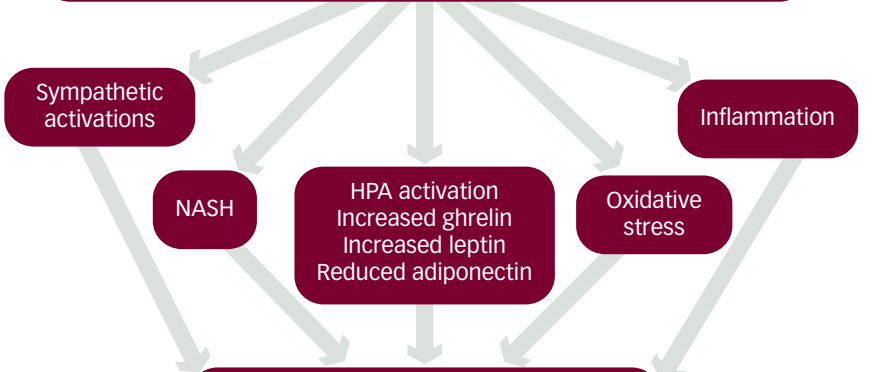

IR, $\beta$-cell dysfunction and type 2 diabetes

HPA = hypothalamic-pituitary-adrenal axis; $I R=$ insulin resistance; $N A S H=$ non-alcoholic steatohepatitis; OSA = obstructive sleep apnoea; REM = rapid eye movement; SWS = slow-wave sleep.

occur in OSA can simulate ischaemia-reperfusion injury and result in the formation of reactive oxygen species (ROS) and reactive nitrogen species (RNS) causing oxidative and nitrosative stress resulting in cellular and DNA damage and increased oxidised lipids, DNA and carbohydrates as shown in patients with OSA and animals exposed to intermittent hypoxia. ${ }^{101,144,146,161}$ The impact of intermittent hypoxia on IR could be in part due to the hypoxia-inducible factor-1 (HIF-1) that is increased in OSA either secondary to hypoxia itself164 or oxidative stress. ${ }^{165}$ HIF-1 upregulates sterol regulatory element-binding protein (SREBP)-1,166 which is associated with increased lipid biosynthesis and IR. ${ }^{167} \mathrm{HIF}$ is also involved in systemic inflammation. ${ }^{168}$ Interestingly, in mice with partial deficiency of HIF-1, intermittent hypoxia does not result in IR. ${ }^{8,166}$

OSA is also associated with many hormonal changes that can affect glucose metabolism including activation of the hypothalamicpituitary-adrenal (HPA) axis, ${ }^{169,170}$ increased ghrelin ${ }^{171}$ and increased catecholamines secretion ${ }^{172}$ all of which can be corrected with CPAP. OSA is also associated with changes in adipokine secretion including lower adiponectin levels, ${ }^{161,173,174}$ and higher leptin levels.48,49

OSA is associated with increased sympathetic activity ${ }^{161}$ that plays an important role in the regulation of glucose and fat metabolism and the development of type 2 diabetes. ${ }^{175}$ Both recurrent hypoxia ${ }^{176}$ and recurrent arousals ${ }^{177}$ probably contribute to the activation of the sympathetic system.

In addition, OSA is associated with elevated inflammatory cytokines such as interleukin (IL)-6, tumour necrosis factor alpha (TNF- $\alpha$ ) and nuclear factor kappa-light-chain-enhancer of activated B cells (NF-KB), ${ }^{161}$ which contributes to IR and $\beta$-cell dysfunction. In addition to intermittent hypoxia, OSA is associated with changes in sleep architecture such as reduction in SWS and sleep quality, which have been associated with reduction in insulin sensitivity and dysglycaemia. ${ }^{178}$

OSA might also be a risk factor for the developing of histologically proven non-alcoholic fatty liver disease (NAFLD) and for progressing to NASH. ${ }^{61,179}$ Nocturnal desaturations were found to be associated with hepatic inflammation, hepatocyte ballooning and liver fibrosis. ${ }^{61}$ Another study also found that subjects with histological NASH had significantly lower mean nocturnal oxygen saturation, and higher AHI compared with non-NASH controls. ${ }^{179}$

All the above-listed mechanisms can impact on IR and/or $\beta$-cell function resulting in impaired glucose metabolism and eventually type 2 diabetes.

\section{Summary and Conclusion}

OSA is a common medical condition that is strongly linked to obesity. It is associated with increased IR and $\beta$-cell dysfunction and is a risk factor for the development of incident glucose intolerance/type 2 diabetes. Obesity remains a major confounder for the relationship between OSA and glycaemic abnormalities but recent studies suggest that these associations hold true even in lean individuals with OSA. The mechanisms underlying this relationship between OSA and dysglycaemia are complex and likely to involve several neural and endocrine mechanisms. OSA is common in patients with type 2 diabetes with most studies showing that more than half of patients with type 2 diabetes have some degree of OSA. OSA is associated with worsening glycaemic control in patients with type 2 diabetes and recent studies suggest that OSA is associated with increased macro- and microvascular complications and possibly hypertension in patients with type 2 diabetes. The mechanisms linking OSA to vascular disease in type 2 diabetes are likely to involve similar pathways to those stimulated by hyperglycaemia in type 2 diabetes. The impact of CPAP treatment in patients with dysglycaemia or type 2 diabetes remains controversial. While CPAP seems to improve $\mathbb{R}$, convincing evidence for the impact of CPAP on glycaemic control in patients with type 2 diabetes is still lacking. Recent observational data suggest that CPAP might have a favourable impact on diabetes-related vascular complication but evidence from randomised controlled trials is awaited. 
While most of the research in the field of OSA and glucose metabolism focussed on euglycaemic individuals or patients with pre-diabetes, research into the impact of OSA in patients with type 2 diabetes is rapidly expanding and gaining momentum. Further research into the impact of mild OSA in patients with type 2 diabetes and randomised controlled trials into the efficacy of OSA treatments on diabetes-related outcomes are needed. In addition, more work needs to be carried out to understand the impact of type 2 diabetes on OSA
1. International Diabetes Federation. IDF Diabetes Atlas [6th]. 2013. Brussels, Belgium, International Diabetes Federation, 9 March 2014.

2. de Groot $M$, Anderson $R$, Freedland KE, et al., Association of depression and diabetes complications: a meta-analysis, Psychosom Med, 2001;63:619-30

3. Jacobson AM, Impact of improved glycemic control on quality of life in patients with diabetes, Endocr Pract, 2004;10:502-8. Stumvoll M, Goldstein BJ, van Haeften TW, Type 2 diabetes: principles of pathogenesis and therapy, Lancet, 2005;365:1333-46.

5. Reaven $\mathrm{GM}$, Role of insulin resistance in human disease, Diabetes, 1988:37:1595-607.

6. Kahn SE, Hull RL, Utzschneider KM, Mechanisms linking obesity to insulin resistance and type 2 diabetes, Nature, 2006:444(7121):840-6.

7. MCNicholas WT, Diagnosis of obstructive sleep apnea in adults, Proc Am Thorac SOC, 2008;5:154-60.

8. Tahrani AA, Bailey CJ, Del PS, Barnett AH, Management of type 2 diabetes: new and future developments in treatment, Lancet, 2011;378:182-97.

9. Scheer FA, Hilton MF, Mantzoros CS, Shea SA, Adverse metabolic and cardiovascular consequences of circadian misalignment, Proc Natl Acad Sci U S A, 2009;106:4453-8.

10. MCMullan CJ, Schernhammer ES, Rimm EB, et al., Melatonin secretion and the incidence of type 2 diabetes, JAMA, 2013:309:1388-96.

11. Leproult $R$, Van CE, Role of sleep and sleep loss in hormonal release and metabolism, Endocr Dev, 2010:17:11-21.

12. Cappuccio FP, Taggart FM, Kandala NB, et al., Meta-analysis of short sleep duration and obesity in children and adults, Sleep, 2008;31:619-26.

13. Iber C, Ancoli-Israel S, Chesson A, Quan S, The AASM Manual for the Scoring of Sleep and Associated Events: Rules, Terminology and Technical Specifications, 1st edition Westchester, llinois, US, American Academy of Sleep Medicine, 2007

14. Epstein LJ, Kristo D, Strollo PJ Jr, et al., Clinical guideline for the evaluation, management and long-term care of obstructive sleep apnea in adults, J Clin Sleep Med, 2009;5:263-76.

15. Young T, Peppard PE, Gottlieb DJ, Epidemiology of obstructive sleep apnea: a population health perspective, Am J Respir Sleep apnea: a population health
Crit Care Med, 2002:165:1217-39.

16. Young T, Shahar E, Nieto FJ, et al., Predictors of sleepdisordered breathing in community-dwelling adults: The Sleep Heart Health Study. Arch Intern Med, 2002:162:893-900.

17. Ip MSM, Lam B, Lauder IJ, et al., A community study of sleepdisordered breathing in middle-aged Chinese men in Hong Kong, Chest, 2001;119:62-9.

18. Ip MSM, Lam B, Tang LCH, et al., A community study of sleepdisordered breathing in middle-aged chinese women in Hong Kong, Chest, 2004;125:127-34.

19. Lam B, Ip MSM, Tench E, Ryan CF, Craniofacial profile in Asian and white subjects with obstructive sleep apnoea, Thorax 2005;60:504-10.

20. Sharma SK, Kumpawat S, Banga A, Goel A, Prevalence and risk factors of obstructive sleep apnea syndrome in a population of Delhi, India, Chest, 2006;130:149-56.

21. Reddy EV, Kadhiravan T, Mishra HK, et al., Prevalence and risk factors of obstructive sleep apnea among middle-aged urban Indians: A community-based study Sleep Med, 2009:10:913-8.

22. Udwadia ZF, Doshi AV, Lonkar SG, Singh Cl, Prevalence of sleepdisordered breathing and sleep apnea in middle-aged urban Indian men, Am J Respir Crit Care Med, 2004;169:168-73.

23. Punjabi NM, The epidemiology of adult obstructive sleep apnea, Proc Am Thorac Soc, 2008;5:136-43.

24. Jordan A, Doug McEvoy R, Gender differences in sleep apnea: epidemiology, clinical presentation and pathogenic mechanisms, Sleep Med Rev, 2003;7:377-89.

25. Bixler EO, Vgontzas AN, Ten HT, et al., Effects of age on sleep apnea in men: I. Prevalence and severity, Am J Respir Crit Care Med, 1998;157:144-8.

26. Young T, Palta M, Dempsey J, et al., The occurrence of sleep-disordered breathing among middle-aged adults, N Engl I Med, 1993:328:1230-5

27. Peppard PE, Young T, Palta M, et al., Longitudinal study of moderate weight change and sleep-disordered breathing, JAMA, 2000:284:3015-21.

28. Newman AB, Foster $\mathrm{G}$, Givelber R, et al., Progression and regression of sleep-disordered breathing with changes in weight: The Sleep Heart Health Study, Arch Intern Med 2005;165:2408-13

29. Tuomilehto HPI, Seppa JM, Partinen MM, et al., Lifestyle intervention with weight reduction: first-line treatment in mild obstructive sleep apnea, Am J Respir Crit Care Med 2009;179:320-7.

30. Greenburg DL, Lettieri CJ, Eliasson AH, Effects of surgica weight loss on measures of obstructive sleep apnea: a meta-analysis, Am J Med, 2009;122:535-42.

31. Fogel RB, Malhotra A, White DP, Sleep. 2: Pathophysiology of obstructive sleep apnoea/hypopnoea syndrome, Thorax 2004;59:159-63.

32. Eckert DI, Malhotra A, Pathophysiology of adult obstructive sleep apnea, Proc Am Thorac Soc, 2008;5:144-53.
33. Mezzanotte WS, Tangel DJ, White DP, Waking genioglossal electromyogram in sleep apnea patients versus normal controls (a neuromuscular compensatory mechanism) J Clin Invest, 1992;89:1571-9.

34. Mezzanotte WS, Tangel DJ, White DP, Influence of sleep onse on upper-airway muscle activity in apnea patients versus normal controls, Am J Respir Crit Care Med, 1996;153:1880-7.

35. Deegan PC, MCNicholas WT, Predictive value of clinical features for the obstructive sleep apnoea syndrome, Eur Respir J, 1996:9:117-24.

36. Elmasry A, Janson C, Lindberg E, et al., The role of habitual snoring and obesity in the development of diabetes: a 10 -year follow-up study in a male population, I Intern Med 2000;248:13-20.

37. Al-Delaimy WK, Manson JE, Willett WC, et al., Snoring as a risk factor for type II diabetes mellitus: a prospective study, Am J Epidemiol, 2002;155:387-93.

38. Reichmuth KJ, Austin D, Skatrud JB, Young T, Association of sleep apnea and type II diabetes: a population-based study, Am J Respir Crit Care Med, 2005;172:1590-5.

39. Marshall NS, Wong KK, Phillips $\mathrm{CL}$, et al., Is sleep apnea an independent risk factor for prevalent and incident diabetes in the Busselton Health Study?, I Clin Sleep Med, 2009:5:15-20.

40. Botros N, Concato J, Mohsenin V, et al., Obstructive sleep apnea as a risk factor for type 2 diabetes, Am J Med, 2009;122:1122-7.

41. Celen YT, Hedner J, Carlson J, Peker Y, Impact of gender on incident diabetes mellitus in obstructive sleep apnea: a 16 incident diabetes mellitus in obstructive sleep ap

42. Lindberg E, Theorell-Haglöw J, Svensson M, et al., Sleep apnea and glucose metabolism: A long-term follow-up in a community-based sample, Chest, 2012;142:935-42.

43. Wang $X, B i$ Y, Zhang $Q$, Pan F, Obstructive sleep apnoea and the risk of type 2 diabetes: A meta-analysis of prospective cohort studies, Respirology, 2013;18:140-6.

44. Punjabi NM, Beamer BA, Alterations in glucose disposal in sleep-disordered breathing, Am J Respir Crit Care Med 2009;179:235-40

45. Tiihonen $\mathrm{M}$, Partinen $\mathrm{M}$, Narvanen $\mathrm{S}$, The severity of obstructive sleep apnoea is associated with insulin resistance, I Sleep Res, 1993;2:56-61.

46. Strohl KP, Novak RD, singer W, et al., Insulin levels, blood pressure and sleep apnea, Sleep, 1994;17:614-8.

47. Grunstein RR, Stenlof $K$, Hedner J, Sjostrom L, Impact of obstructive sleep apnea and sleepiness on metabolic and cardiovascular risk factors in the Swedish obese Subjects (SOS) Study, Int I Obes Relat Metab Disord, 1995;19:410-8.

48. Ip MSM, Lam KS, Ho C, et al., Serum leptin and vascular risk factors in obstructive sleep apnea, Chest, 2000;118:580-6.

49. Vgontzas AN, Papanicolaou DA, Bixler EO, et al., Sleep apne and daytime sleepiness and fatigue: relation to visceral obesity, insulin resistance, and hypercytokinemia, J Clin Endocrinol Metab, 2000;85:1151-8.

50. Ip MS, Lam B, Ng MM, et al., Obstructive sleep apnea is independently associated with insulin resistance, $\mathrm{Am}$ Respir Crit Care Med, 2002:165:670-6.

51. Manzella D, Parillo M, Razzino T, et al., Soluble leptin receptor and insulin resistance as determinant of sleep apnea, Int J Obes Relat Metab Disord, 2002;26:370-5.

52. Punjabi NM, Sorkin ID, Katzel 1 et al Sleep-disordered breathing and insulin resistance in middle-aged and overweight men, Am J Respir Crit Care Med, 2002;165:677-82.

53. Meslier N, Gagnadoux F, Giraud P, et al., Impaired glucoseinsulin metabolism in males with obstructive sleep apnoea syndrome, Eur Respir J, 2003;22:156-60

54. Tassone F, Lanfranco F, Gianotti L, et al., Obstructive sleep apnoea syndrome impairs insulin sensitivity independently of anthropometric variables, Clin Endocrinol, 2003;59:374-9.

55. Barcelo A, Barbe F, Llompart E, et al., Effects of obesity on C-reactive protein level and metabolic disturbances in male patients with obstructive sleep apnea, Am J Med, 2004;117:118-21.

56. Punjabi NM, Shahar E, Redline S, et al., Sleep-disordered breathing, glucose intolerance, and insulin resistance: The Sleep Heart Health Study, Am J Epidemiol, 2004;160:521-30.

57. Makino $S$, Handa $H$, Suzukawa K, et al., Obstructive sleep apnoea syndrome, plasma adiponectin levels, and insulin resistance, Clin Endocrinol (OXf), 2006;64:12-9.

58. McArdle N, Hillman D, Beilin L, Watts $G$, Metabolic Risk Factors for Vascular Disease in Obstructive Sleep Apnea Am J Respir Crit Care Med, 2007;175:190-5.

59. Theorell-Haglow J, Berne C, Janson C, Lindberg E, Obstructiv sleep apnoea is associated with decreased insulin sensitivity in females, Eur Respir J, 2008;31:1054-60.

60. Tkacova R, Dorkova Z, Molcanyiova A, et al., Cardiovascular risk and insulin resistance in patients with obstructive sleep apnea, Med Sci Monit, 2008:14:CR438-44.

61. Polotsky VY, Patil SP, Savransky V, et al., Obstructive Sleep Apnea, Insulin Resistance, and Steatohepatitis in Severe Obesity, Am J Respir Crit Care Med, 2009:179:228-34.

62. Bhushan B, Misra A, Guleria R, Obstructive sleep apnea is independently associated with the metabolic syndrome in obese Asian Indians in northern India, Metab Syndr Relat Disord, 2010;8:431-5.

63. Togeiro SM, Carneiro G, Ribeiro Filho FF, et al., Consequences of obstructive sleep apnea on metabolic profile: a population-based survey, Obesity, 2013;21:8475-51.

64. Elmasry A, Lindberg E, Berne C, et al., Sleep-disordered breathing and glucose metabolism in hypertensive men: a population-based study, I Intern Med, 2001;249:153-61.

65. Davies RJ, Turner R, Crosby J, Stradling JR, Plasma insulin and lipid levels in untreated obstructive sleep apnoea and snoring; their comparison with matched controls and response to treatment, I Sleep Res, 1994;3:180-5.

66. Stoohs RA, Facchini F, Guilleminault C, Insulin resistance and sleep-disordered breathing in healthy humans, Am J Respir Crit Care Med, 1996:154:170-4.

67. Saarelainen S, Lahtela J, Kallonen E. Effect of nasal CPAP treatment on insulin sensitivity and plasma leptin, J Sleep Res, 1997;6:146-7

68. Gruber A, Horwood F, Sithole J, et al., Obstructive sleep apnoea is independently associated with the metabolic syndrome but not insulin resistance state, Cardiovasc Diabetol, 2006;5:22.

69. Sharma SK, Kumpawat S, Goel A, et al., Obesity, and not obstructive sleep apnea, is responsible for metabolic abnormalities in a cohort with sleep-disordered breathing Sleep Med, 2007;8:12-7.

70. Onat $A$, Hergenc $G$, Uyarel $H$, et al., Obstructive sleep apnea syndrome is associated with metabolic syndrome rather than insulin resistance, Sleep Breath, 2007:11:23-30.

71. Kapsimalis $F$ varouchakis $G$, Manousaki A, et al., Association of sleep apnea severity and obesity with insulin resistance c-reactive protein, and leptin levels in male patients with obstructive sleep apnea, Lung, 2008;186:209-17.

72. Barcelo $A$, Barbe $F$, de la Pena $M$, et al., Insulin resistance and daytime sleepiness in patients with sleep apnoea, Thorax, 2008;63:946-50.

73. Nena E, Steiropoulos P, Papanas N, et al., Sleepiness as a marker of glucose deregulation in obstructive sleep apnea, Sleep Breath, 2012;16:181-6.

74. Schahin SP, Nechanitzky T, Dittel C, et al., Long-term improvement of insulin sensitivity during CPAP therapy in the obstructive sleep apnoea syndrome, Med Sci Monit, 2008;14:CR117-21.

75. Tasali E, Chapotot F, Leproult R, et al., Treatment of obstructive sleep apnea improves cardiometabolic function in young obese women with polycystic ovary syndrome J Clin Endocrinol Metab, 2011;96:365-74.

76. West SD, Nicoll DJ, Wallace TM, et al. Effect of CPAP on insulin resistance and $\mathrm{HbA1C}$ in men with obstructive sleep apnoea and type 2 diabetes, Thorax, 2007;62:969-74.

77. Hoyos CM, Killick R, Yee BJ, et al., Effects of testosterone therapy on sleep and breathing in obese men with severe obstructive sleep apnoea: a randomized placebo-controlled trial, Clin Endocrinol, 2012;77:599-607.

78. Kritikou I, Basta M, Vgontzas AN, et al., Sleep apnea, sleepiness, inflammation and insulin resistance in middleaged men and women, Eur Respir J, 2013;43:145-55.

79. Yang D, Liu Z, Yang H, Luo Q, Effects of continuous positive airway pressure on glycemic control and insulin resistance in patients with obstructive sleep apnea: a meta-analysis, Sleep Breath, 2013;17:33-8.

80. Iftikhar IH, Khan MF, Das A, Magalang UJ, Meta-analysis: continuous positive airway pressure improves insulin resistance in patients with sleep apnea without diabetes, resistance in patients with sleep apn
Ann Am Thorac Soc, 2013;10:115-20.

81. Yang $D$, Liu Z, Yang $H$, The impact of effective continuous positive airway pressure on homeostasis model assessment insulin resistance in non-diabetic patients with moderate to severe obstructive sleep apnea, Diabetes Metab Res Rev, 2012;28:499-504

82. Pamidi S, Wroblewski K, Broussard J, et al., Obstructive sleep apnea in young lean men: impact on insulin sensitivity and secretion, Diabetes Care, 2012;35:2384-9.

83. Lin QC, Zhang XB, Chen GP, et al., Obstructive sleep apnea syndrome is associated with some components of metabolic syndrome in nonobese adults, Sleep Breath, 2012;16:571-8.

84. Kim NH, Cho NH, Yun CH, et al., Association of obstructive sleep apnea and glucose metabolism in subjects with or Sleep apnea and glucose metabolism in subjects with

85. Duarte FH, Jallad RS, Amaro AC, et al., The impact of sleep apnea treatment on carbohydrate metabolism in patients with acromegaly, Pituitary, 2012;16:341-50.

86. Xu J, Long YS, Gozal D, Epstein PN, B-cell death and proliferation after intermittent hypoxia: Role of oxidative stress, Free Radic Biol Med, 2009;46:783-90.

87. Wang N, Khan SA, Prabhakar NR, Nanduri J, Impaired Pancreatic Beta Cell Function by Chronic Intermitten Hypoxia, Exp Physiol, 2013;98:1376-85.

88. Hermans MP, Ahn SA, Mahadeb YP, Rousseau MF, Sleep apnoea syndrome and 10-year cardiovascular risk in females with type 2 diabetes: relationship with insulin secretion and insulin resistance, Diabetes Metab Res Rev, 2013;29:227-34.

89. Tantucci C, Scionti L, Bottini P, et al., Influence of autonomic neuropathy of different severities on the hypercapnic drive to breathing in diabetic patients, Chest, 1997:112:145-53. 
Pathophysiological findings in a patient with Shy-Drager and alveolar hypoventilation syndromes, Chest, 1988:94:212-4.

91. Balkau B, Vol S, Loko S, et al., High baseline insulin levels associated with 6-year incident observed sleep apnea, Diabetes Care, 2010;33:1044-9.

92. Brooks B, Cistulli PA, Borkman M, et al., Obstructive sleep apnea in obese noninsulin-dependent diabetic patients: effect of continuous positive airway pressure treatment on insulin responsiveness, J Clin Endocrinol Metab, 1994:79:1681-5

93. Resnick HE, Redline S, Shahar E, et al., Diabetes and sleep disturbances: Findings from the Sleep Heart Health Study, Diabetes Care, 2003;26:702-9.

94. West SD, Nicoll DJ, Stradling JR, Prevalence of obstructive sleep apnoea in men with type 2 diabetes, Thorax, 2006;61:945-50.

95. Einhorn D, Stewart DA, Erman MK, et al., Prevalence of sleep apnea in a population of adults with type 2 diabetes mellitus, Endocr Pract, 2007; 13:355-62.

96. Laaban JP, Daenen S, Léger D, et al., Prevalence and predictive factors of sleep apnoea syndrome in type-2 diabetic patients, Diabetes Metab, 2009;35:372-7.

97. Foster GD, Sanders MH, Millman R, et al., Obstructive sleep apnea among obese patients with type 2 diabetes, Diabetes Care, 2009:32:1017-9.

98. Lam DCL, Lui MMS, Lam JCM, et al., Prevalence and recognition of obstructive sleep apnea in Chinese patients with type 2 diabetes mellitus, Chest, 2010:138:1101-7.

99. Schober AK, Neurath ME, Harsch IA, Prevalence of sleep apnoea in diabetic patients, Clin Respir J, 2011:5:165-72.

100. Pillai A, Warren $G$, Gunathilake W, Idris I, Effects of sleep apnea severity on glycemic control in patients with typ 2 diabetes prior to continuous positive airway pressure treatment, Diabetes Technol Ther, 2011;13:945-9.

101. Tahrani AA, Ali A, Raymond NT, et al., Obstructive sleep apnea and diabetic neuropathy: a novel association in patients with type 2 diabetes, Am J Respir Crit Care Med, 2012;186:434-41

102. Heffner JE, Rozenfeld $Y$, Kai M, et al., Prevalence of diagnosed sleep apnea among patients with type 2 diabetes in primary care, Chest, 2012;141:1414-21.

103. Lecomte $P$, Criniere L, Fagot-Campagna $A$, et al, Underdiagnosis of obstructive sleep apnoea syndrome in patients with type 2 diabetes in France: ENTRED 2007, Diabetes Metab, 2013;39:139-47.

104. Shaw JE, Punjabi NM, Wilding JP, et al., Sleep-disordered breathing and type 2 diabetes: A report from the International Diabetes Federation Taskforce on Epidemiolog and Prevention, Diabetes Res Clin Pract, 2008;81:2-12.

105. Drager LF, Queiroz EL, Lopes HF, et al., Obstructive sleep apnea is highly prevalent and correlates with impaired glycemic control in consecutive patients with the metabolic syndrome, I Cardiometab Syndr, 2009;4:89-95.

106. Papanas N, Steiropoulos P, Nena E, et al., HbA1C is associated with severity of obstructive sleep apnea hypopnea syndrome in nondiabetic men, Vasc Health Risk Manag, 2009;5:751-6.

107. Kosseifi S, Bailey $B$, Price $R$, et al. The association between obstructive sleep apnea syndrome and microvascular complications in well-controlled diabetic patients, Mil Med, 2010;175:913-6.

108. Aronsohn RS, Whitmore $H$, Van Cauter $E$, Tasali E, Impact of untreated obstructive sleep apnea on glucose control in type 2 diabetes, Am J Respir Crit Care Med, 2010;181:507-13.

109. Pamidi S, Tasali E, Obstructive sleep apnea and type 2 diabetes: is there a link?, Front Neurol, 2012;3:126.

110. Tamura A, Kawano $Y$, Watanabe T, Kadota J, Obstructive sleep apnea increases hemoglobin A1c levels regardless of glucose tolerance status, Sleep Med, 2012;13:1050-5.

111. Grimaldi D, Beccuti G, Touma C, et al., Association of obstructive sleep apnea in REM sleep with reduced glycemic control in type 2 diabetes: Therapeutic implications, Diabetes Care, 2014:37:355-63.

112. Harsch IA, Schahin SP, Bruckner $K$, et al., The effect of continuous positive airway pressure treatment on insulin sensitivity in patients with obstructive sleep apnoea syndrome and type 2 diabetes, Respiration, 2004;71:252-9.

113. Babu AR, Herdegen J, Fogelfeld L, et al., Type 2 diabetes, glycemic control, and continuous positive airway pressure in obstructive sleep apnea, Arch Intern Med, 2005;165:447-52.

114. Hassaballa HA, Tulaimat A, Herdegen JJ, Mokhlesi B, The effect of continuous positive airway pressure on glucose control in diabetic patients with severe obstructive sleep apnea, Sleep Breath, 2005;9:176-80.

115. Dawson A, Abel SL, Loving RT, et al., CPAP therapy of obstructive sleep apnea in type 2 diabetics improves glycemic control during sleep, J Clin Sleep Med, 2008;4:538-42.

116. Pallayova $M$, Donic $V$, Tomori Z, Beneficial effects of severe sleep apnea therapy on nocturnal glucose control in persons with type 2 diabetes mellitus, Diabetes Res Clin Pract, 2008;81(1):e8-11.

117. Shpirer I, Rapoport M, Stav D, Elizur A, Normal and elevated HDA1C levels correlate with severity of hypoxemia in patients with obstructive sleep apnea and decrease following CPAP treatment, Sleep Breath, 2012;16:461-6.

118. Tasali E, Abraham V, Aronsohn R, et al., Effective CPAP treatment of obstructive sleep apnea improves glycemic control in type 2 diabetics, Sleep, 2013;36(Abstract Suppl.):124, Abstract 0344.

119. Hla KM, Young $T$, Finn $L$, et al., Longitudinal association of sleep-disordered breathing and nondipping of nocturnal blood pressure in the Wisconsin Sleep Cohort Study, Sleep 2008:31:795-800.
120. Nieto FJ, Young TB, Lind BK, et al., Association of sleeplarge community-based study, JAMA, 2000;283:1829-36.

121. Peppard PE, Young T, Palta M, Skatrud J, Prospective study of the association between sleep-disordered breathing and hypertension, N Eng/ J Med, 2000;342:1378-84.

122. Guillot M, Sforza E, Achour-Crawford E, et al., Association between severe obstructive sleep apnea and incident arterial hypertension in the older people population, Sleep Med, 2013:14:838-42.

123. Barbe F, Duran-Cantolla J, Capote F, et al., Long-term effect of continuous positive airway pressure in hypertensive patients with sleep apnea, Am J Respir Crit Care Med, 2010;181:718-26.

124. Joaquin D, Felipe A, Jose MM, et al., Continuous positive airway pressure as treatment for systemic hypertension in people with obstructive sleep apnoea: randomised controlled trial, BMJ, 2010;341:c5991.

125. Prasad B, Carley DW, Krishnan JA, et al., Effects of positive airway pressure treatment on clinical measures of hypertension and type 2 diabetes, $J$ Clin Sleep Med, 2012;8:481-7.

126. Myhill PC, Davis WA, Peters KE, et al., Effect of continuous positive airway pressure therapy on cardiovascular risk factors in patients with type 2 diabetes and obstructive sleep apnea, J Clin Endocrinol Metab, 2012;97:4212-8.

127. Peker Y Hedner 」 Norum 」, et al. Increased incidence of cardiovascular disease in middle-aged men with obstructive sleep apnea: a 7-year follow-up, Am J Respir Crit Care Med 2002;166:159-65.

128. Marin JM, Carrizo SJ, Vicente E, Agusti AG, Long-term cardiovascular outcomes in men with obstructive sleep apnoea-hypopnoea with or without treatment with continuous positive airway pressure: an observational study, Lancet, 2005;365(9464):1046-53

129. Yaggi HK, Concato J, Kernan WN, et al., Obstructive sleep apnea as a risk factor for stroke and death, N Eng/ I Med 2005;353:2034-41.

130. Turmel J, Sériès F, Boulet LP, et al., Relationship between atherosclerosis and the sleep apnea syndrome: An intravascular ultrasound study Int I Cardiol 2009:132:203-9.

131. Kent BD, Garvey JF, Ryan S, et al., Severity of obstructive sleep apnoea predicts coronary artery plaque burden: a coronary apnoea predicts coronary artery plaque burden: a coron
CT angiography study, Eur Respir J, 2013;42:1263-70

132. Sert Kuniyoshi FH, Garcia-Touchard A, Gami AS, et al., Daynight variation of acute myocardial infarction in obstructive sleep apnea, J Am Coll Cardiol, 2008;52:343-6.

133. Rice TB, Foster GD, Sanders MH, et al., The relationship between obstructive sleep apnea and self-reported stroke or coronary heart disease in overweight and obese adults with type 2 diabetes mellitus, Sleep, 2012;35:1293-8.

134. Seicean S, Strohl KP, Seicean A, et al., Sleep disordered breathing as a risk of cardiac events in subjects with diabetes mellitus and normal exercise echocardiographic findings, Am J Cardiol, 2013;111:1214-20.

135. Shiba T, Maeno T, Saishin Y, et al., Nocturnal intermittent serious hypoxia and reoxygenation in proliferative diabetic retinopathy cases, Am J Ophthalmol, 2010:149:959-63.

136. West SD, Groves DC, Lipinski HJ, et al., The prevalence of retinopathy in men with type 2 diabetes and obstructive sleep apnoea, Diabet Med, 2010;27:423-30.

137. Tahrani AA, Dodson P, Ali A, et al., Obstructive sleep apnoea is associated with sight threatening retinopathy and predicts the development of preproliferative and proliferative retinopathy in patients with type 2 diabetes: a longitudinal analysis, Eur J Ophthalmol, 2013:23:449.

138. Mason RH, Kiire CA, Groves DC, et al., Visual improvement following continuous positive airway pressure therapy in diabetic subjects with clinically significant macular oedema and obstructive sleep apnoea: proof of principle study, Respiration, 2012;84:275-82.

139. Tahrani AA, Ali A, Raymond NT, et al., Obstructive sleep apnea and diabetic nephropathy: a cohort study, Diabetes Care, 2013:36:3718-25.

140. Furukawa S, Saito I, Yamamoto S, et al., Nocturnal intermittent hypoxia as an associated risk factor for microalbuminuria in Japanese patients with type 2 diabetes mellitus, Eur J Endocrinol, 2013;169:239-46.

141. Brownlee M, Biochemistry and molecular cell biology of diabetic complications, Nature, 2001;414:813-20.

142. Brownlee M, The pathobiology of diabetic complications: a unifying mechanism, Diabetes, 2005:54:1615-25.

143. Tahrani AA, Askwith T, Stevens MJ, Emerging drugs for diabetic neuropathy, Expert Opin Emerg Drugs, 2010;15:661-83.

144. Tasali E, Ip MS, Obstructive sleep apnea and metabolic syndrome: alterations in glucose metabolism and inflammation, Proc Am Thorac Soc, 2008;5:207-17.

145. Dyugovskaya L Lavie P Lavie L Increased adhesion molecules expression and production of reactive oxygen species in leukocytes of sleep apnea patients, Am J Respir Crit Care Med, 2002;165:934-9.

146. Lavie L, Oxidative stress - a unifying paradigm in obstructive sleep apnea and comorbidities, Prog Cardiovasc Dis, 2009;51:303-12.

147. Schulz R, Mahmoudi S, Hattar K, et al., Enhanced release of superoxide from polymorphonuclear neutrophils in obstructive sleep apnea. Impact of continuous positive airway pressure therapy, Am J Respir Crit Care Med 2000;162(2 Pt 1):566-70.

148. Barcelo A, Miralles C, Barbe F, et al., Abnormal lipid peroxidation in patients with sleep apnoea, Eur Respir J 2000;16:644-7.

149. Carpagnano GE, Kharitonov SA, Resta O, et al., 8-Isoprostane, condensate of patients with obstructive sleep apnea after night and is reduced by continuous positive airway pressure therapy, Chest, 2003:124:1386-92.

150. Lavie L Vishnevsky A, Lavie P. Evidence for lipid peroxidation in obstructive sleep apnea, Sleep, 2004;27:123-8.

151. Minoguchi K, Yokoe T, Tanaka A, et al., Association between lipid peroxidation and inflammation in obstructive sleep apnoea, Eur Respir J, 2006;28:378-85.

152. Yamauchi M, Nakano $\mathrm{H}$, Maekawa J, et al., Oxidative stress in obstructive sleep apnea, Chest, 2005;127:1674-9.

153. Jelic S, Lederer DJ, Adams T, et al., Vascular inflammation in obesity and sleep apnea, Circulation, 2010;121:1014-2

154. Tan KC, Chow WS, Lam JC, et al., Advanced glycation endproducts in nondiabetic patients with obstructive sleep apnea, Sleep, 2006;29:329-33.

155. Allahdadi KJ, Duling LC, Walker BR, Kanagy NL, Eucapnic intermittent hypoxia augments endothelin-1 vasoconstriction in rats: role of PKC\{delta\}, Am J Physio Heart Circ Physiol, 2008;294(2):H920-7.

156. de la Pena M, Barcelo A, Barbe F, et al., Endothelial function and circulating endothelial progenitor cells in patients with sleep apnea syndrome, Respiration, 2008;76:28-32.

157. Lavie L Kraiczi H, Hefetz A et al Plasma vascular endothelial growth factor in sleep apnea syndrome: effects of nasal continuous positive air pressure treatment, Am J Respir Crit Care Med, 2002:165:1624-8.

158. Schulz R, Hummel C, Heinemann S, et al., Serum levels of vascular endothelial growth factor are elevated in patients with obstructive sleep apnea and severe nighttime hypoxia, Am J Respir Crit Care Med, 2002;165:67-70.

159. Valipour A, Litschauer B, Mittermayer F, et al., Circulating plasma levels of vascular endothelial growth factor in patients with sleep disordered breathing, Respir Med, 2004;98:1180-6

160. Rangemark C, Hedner JA, Carlson JT, et al., Platelet-function and fibrinolytic-activity in hypertensive and normotensive sleep-apnea, Sleep, 1995:18:188-94.

161. Arnardottir ES, Mackiewicz M, Gislason T, et al., Molecular signatures of obstructive sleep apnea in adults: a review and perspective, Sleep, 2009:32:447-70

162. Atkeson A, Yeh SY, Malhotra A, Jelic S, Endothelial function in obstructive sleep apnea, Prog Cardiovasc Dis, 2003;51:351-62.

163. Louis M, Punjabi NM, Effects of acute intermittent hypoxia on glucose metabolism in awake healthy volunteers, $J$ App Physiol, 2009;106:1538-44

64. Semenza GL, HIF-1 and mechanisms of hypoxia sensing Curr Opin Cell Biol, 2001;13:167-71.

165. Prabhakar NR, Kumar GK, Nanduri J Intermittent hypoxia augments acute hypoxic sensing via HIF-mediated ROS, Respir Physiol Neurobiol, 2010;174:230-4.

166. Li J, Bosch-Marce M, Nanayakkara A, et al., Altered metabolic responses to intermittent hypoxia in mice with partia deficiency of hypoxia-inducible factor-1a, Physiol Genomics, 2006;25:450-7.

167. Shimomura I, Matsuda M, Hammer RE, et al., Decreased IRS2 and increased SREBP-1c lead to mixed insulin resistance and sensitivity in livers of lipodystrophic and ob/ob mice, $\mathrm{Mol}$ Cell, 2000;6:77-86.

68. Cramer T, Yamanishi Y, Clausen BE, et al., HIF-1a is essential for myeloid cell-mediated inflammation, Cell, 2003;112:645-7.

69. Carneiro G, Togeiro SM, Hayashi LF, et al., Effect of continuous positive airway pressure therapy on hypothalamic-pituitaryadrenal axis function and 24-h blood pressure profile in obese men with obstructive sleep apnea syndrome, Am J Physiol Endocrinol Metab, 2008:295:E380-4.

170. Cooper BG, White JE, Ashworth LA, et al., Hormonal and metabolic profiles in subjects with obstructive sleep apnea syndrome and the acute effects of nasal continuous positive syndrome and the acute effects of nasal continuous positive

171. Takahashi K, Chin K, Akamizu T, et al., Acylated ghrelin level in patients with OSA before and after nasal CPAP treatment, Respirology, 2008:13:810-6.

172. Kahal H, Tahrani AA, George JT, et al., Obstructive sleep apnoea; a rare cause of pseudophaeochromocytoma, QJM 2013;106:1133-6

173. Lam JC, XU A, Tam S, et al., Hypoadiponectinemia is related to sympathetic activation and severity of obstructive sleep apnea, Sleep, 2008:31:1721-7.

174. Kohler M, Ayers L, Pepperell JC, et al., Effects of continuous positive airway pressure on systemic inflammation in patients with moderate to severe obstructive sleep apnoea: a randomised controlled trial, Thorax, 2009;64:67-73.

175. Esler M, Rumantir M, Wiesner $G$, et al., Sympathetic nervous system and insulin resistance: from obesity to diabetes, Am J Hypertens, 2001:14(11S):304S-9S.

176. Xie A, Skatrud JB, Puleo DS, Morgan BJ, Exposure to hypoxia 